Володимир Володимирович Соколов, кандидат технічних наук, доцент, доцент кафедри кібербезпеки та застосування автоматизованих інформаційних систем та технологій, Інститут спеціального зв'язку та захисту інформації Національного технічного університету “Київський політехнічний інститут імені Ігоря Сікорського”, Київ, Україна.

E-mail:vsokolov@i.ua.

Владимир Владимирович Соколов, кандидат технических наук, доцент, доцент кафедры кибербезопасности и применения автоматизированных информационных систем и технологий, Институт специальной связи и защиты информации Национального технического университета "Киевский политехнический институт имени Игоря Сикорского”, Киев, Украина.

Volodymyr Sokolov, candidate of technical sciences, associate professor, associate professor at the cybersecurity and application of automated information systems and technologies academic department, Institute of special communication and information protection National technical University of Ukraine "Igor Sikorsky Kyiv Polytechnic Institute”, Kyiv, Ukraine..

UDC 510.254:517.977.5

HRYHORII KRAVTSOV

\title{
SEMANTIC INTEROPERABILITY AS A BASIS OF MEANINGFUL ANALYTICS
}

The main objective of the article is to show how ontologies, which are basic items of the semantic interoperability, can be used as a basis of meaningful analytics. It opens the way to solve a lot of problems like expert selection. The author discovers the pointed problem on the boarder between information technologies and recruitment problems like boolean search. The article contains a real example of boolean search query regarding information technologies such J2EE, JDBC, JAXB, JPA, Servlets, JAX-WS and others. The weekness of understanding of meaning some terms by a finder leads to incorrect results of the search. Only ontologies can handle synonyms and other kinds of relations between two terms - it is very important for avoiding of a confusion. Unfortunately, where is a misunderstanding of meaning following terms - classification, taxonomy, ontology. The existing articles do not solve the problem of unified understanding - it is an aspect of author's investigation. The author shows how the analytical hierarchy process in the couple with ontologies can be used for empowering of existing approaches for solving the problem of expert selection. All conclusions are based on the detailed analysis of existing open publications. The pointed combination opens new horizons for predictive meaningful analytics.

Keywords: semantic web, semantic interoperability, ontology, taxonomy, classification, intelligent search, predictive analytics, prescriptive analytics, meaningful analytics.

Problem statement. Search engines, used in the real life for finding of experts, are not very intelligent and therefore it is often difficult to find what you are looking for. I would like to draw specialist's attention to the problem of using "boolean" search. It has been more and more obvious that keywords matching including synonyms is not sufficient for recruitment. As an Mathematician and computer scientist I have many times noticed that the boolean search leads to various issues. Furthermore, the boolean search has disadvantage - you cannot define priorities for terms. It means that they do not provide any functionality for meaningful analysis.

Analysis of recent researches and publications [1] - [17]. I will investigate the "smart" query pointed out by Jacco Valkenburg on "Global Recruiting Roundtable" [5] and will explain why a search engine returns a great number of false-positive CVs.

(C) H. Kravtsov, 2017 
Let us suppose that we are looking for an individual with JAVA experience. This is the query for finding someone with JAVA knowledge using the boolean search: "J2EE" OR "Java Web Start" OR "IntelliJ IDEA" OR "Eclipse" OR "JDBC" OR "Maven" OR "NetBeans" OR "Mockito" OR "JAXB" OR "Tomcat" OR "JPA" OR "Servlets" OR “Ant" OR "JAX-WS" OR "JSP” OR "EJB" OR "Java" OR "Maven2" OR "JNI" OR "GWT” OR "Acegi”.

At first look, this query indicates that it has been prepared by a non-IT-expert. It is easy to proof because the term "Maven" OR "Maven2" has no sense. Any search engines will find "Maven" and "Maven2" because these two words contain "Maven" as a substring.

The query contains names of Integrated Development Environments (IDE) such as IntelliJ, Eclipse and NetBeans.

JetBrains is a company, which develops IntelliJ and indicates on its site: "While IntelliJ IDEA is an IDE for Java, it also understands many other languages, including Groovy, Kotlin, Scala, JavaScript, TypeScript and SQL." It means that including IntelliJ in a query will lead to finding developers on Groovy, Kotlin, Scala, JavaScript and TypeScript at least. Similar situation with Eclipse. There are a lot of plugins for Eclipse IDE for programming languages $\mathrm{C}++$, Ada, JavaScript and ect. This term in the query will also lead to information noise because search results will include CVs of any developer who uses this IDE. I can mention similar problems with NetBeans since NetBeans can be used by C++, PHP, Groovy also. As a result recruiters will receive a lot of falsepositive CVs of developers. I can understand this situation because recruiters don't know all features of IDEs. The correct recommendation is to avoid using IDE's names in queries if you don't want to find a candidate with specified skill of IDE that fits in accordance to corporate politics - some companies use only IntelliJ IDEA others - NetBeans only. I know companies where developers are free in their selection of which IDE to use.

To present an example about issues with the keyword IDE I would like to share following real situation. We were looking for java developers who use Eclipse, IntelliJ IDEA and NetBeans but have found individuals who use these IDE's for coding on Java, Groovy, Kotlin, Scala, JavaScript, TypeScript, $\mathrm{C} / \mathrm{C}++$, Ada, PHP and etc. because the same IDE can be used for coding in different languages.

You can find "Maven", "Maven2" and "Ant" in the query. About "Maven" and "Maven2" I have mentioned the issue above. Now I want to discuss the situation with using "Maven" and "Ant" in a query for searching a java developer. HR cannot know that Maven can also be used to build and manage projects written in C\#, Ruby, Scala, and other languages. On the official site of Ant we can read that "Ant can also be used effectively to build non Java applications, for instance C or C++ applications. More generally, Ant can be used to pilot any type of process which can be described in terms of targets and tasks." This is a similar situation like with IDEs. As already mentioned above the sub-query "Maven" OR "Maven2" OR "Ant" is obviously a cause which generates a lot of falsepositive search results.

The Apache Tomcat ${ }^{\circledR}$ software is an open source implementation of the Java Servlet, JavaServer Pages, Java Expression Language and Java WebSocket technologies. The Java Servlet, JavaServer Pages, Java Expression Language and Java WebSocket specifications are developed under the Java Community Process. What is wrong with using Tomcat in the query? At first look, using Tomcat as term in the query is correct. But not all HRs know that Tomcat can be administered by a system administrator. For example, Web Server Administrator Resume where you can find "Installed, Deployed and maintenance of Enterprise Applications on Tomcat". As a consequence, additional information noise in search and additional false-positive matched CVs are the result.

The query contains J2EE OR "JDBC" OR "JAXB" OR "JPA" OR "Servlets" OR "JAX-WS" OR "JSP" OR "EJB" OR "Java" OR "JNI". Yes, they are meaning: JDBC - Java DataBase Connectivity; J2EE - Java 2 Enterprise Edition; JAXB - Java Architecture for XML Binding; JPA Java Persistence API; JAX-WS - Java API for XML Web Services; JSP - JavaServer Pages ; EJB Enterprise Java Beans; JNI - Java Native Interface. As you can see, the listed elements of Java's stack are not synonyms. They are rather the related conceptions where Java is a common part. Furthermore, a part of them is a subset of J2EE's stack. Unfortunately, I do not know of any HR who knows J2EE's 
stack. All these keywords in the author's edition of the query can be replaced by a single "Java" keyword. Other terms like "Mockito" OR "GWT" OR "Acegi" are tool-kits or frameworks written in Java and used with Java only. I can assume that a likelihood to come across a CV where Java's framework specifications are listed but not to specify Java is an infinitesimal. It means that including these terms in a query is an excess without significant value.

The author, Jacco Valkenburg [5] writes: "It will cost you only 30 seconds extra to create this extensive boolean search string. If you run this query, you come to a total of 31.988 results. That are 3215 or $+11 \%$ more profiles than your competitors have seen and approached!" But regrets that the boolean search technique "has the disadvantage that you quickly introduce false-positive results."

As it has been clearly displayed the false-positive results were introduced not by the technique, but rather by the lack of comprehensive knowledge of HR in the field of Java technology. Furthermore, the boolean search has disadvantage - you cannot define priorities for terms. It means that all terms included in a query have equal importance.

The main material [1] - [17]. There is a solution for these problems. The solution is found by using taxonomies of hard and soft skills.

Let's start by answering the question on what is semantic interoperability and why it is very important for expert selection and predictive analytics and why are ontologies so important for the semantic interoperability. Here are some definitions of semantic interoperability [5]. "Semantic interoperability:

- denotes the ability of different applications and business partners to understand exchanged data in a similar way, implying a precise and unambiguous meaning of the exchanged information;

- the ability to exchange and use information between two or more entities;

- the ability of two or more computer systems to exchange information and have the meaning of that information accurately and automatically interpreted by the receiving system".

As you can see the main advantage of semantic interoperability is a precise and unambiguous meaning of exchanged information. Let's investigate the importance of interoperability regarding HR sphere.

I suppose that medicine and HR have a lot in common - they are oriented on the improvement of human life. This assumption gives me the right to transfer some benefits of semantic interoperability from healthcare into HR sphere. Bob Adams [5] explains Top 5 benefits of semantic interoperability in application to medicine issues where a meaningful analytics holds the first position. This advantage is reached by using ontologies into information systems.

Generally speaking, in the context of computer and information science, we can imagine the concept of ontology as an equivalent of some data model with meaning (semantic data model). A more correct concept of ontology has been defined by Tom Guber [5]. There is an opinion that the ontology term is a synonym for concepts of taxonomy and classification. If you have the same opinion, please, find time to read the article of Reinout van Rees [6] and the discussion with Dr. Search [6]. From a mathematical point of view, set of ontologies is a superset for classifications, set of classifications is a superset for taxonomies. It means, that all laws of classifications are correct for taxonomies and ontologies.

Ontology has found a place in the global vision in a model of Semantic Web [6] in 2006 (see fig.1). Nevertheless, the power of ontology usage has been understood as early as 2004. Jeffrey T. Pollock and Ralph Hodgson in the same year published an incredible book "Adaptive Information: Improving Business Through Semantic Interoperability, Grid Computing, and Enterprise Integration" [6]. What can ontology bring to solve a problem of expert selection?

First, unified understanding and usage of terminologies of skills, competences, occupations and qualifications between a candidate and an HR specialist.

Second, precise and unambiguous matching between vacancy profiles and candidate profiles (as it was shown in the problem description).

Third, easy migration from one HR system to another, which is critical in case of merger, acquisition or any other incorporating actions. It is very important for the whole HR market because it will be a stimulus for HR system vendors to compete in the development of new features. Today 
we have a dramatic situation in this field because changing HR systems is very expensive and risky since some useful data can be lost during database migration.

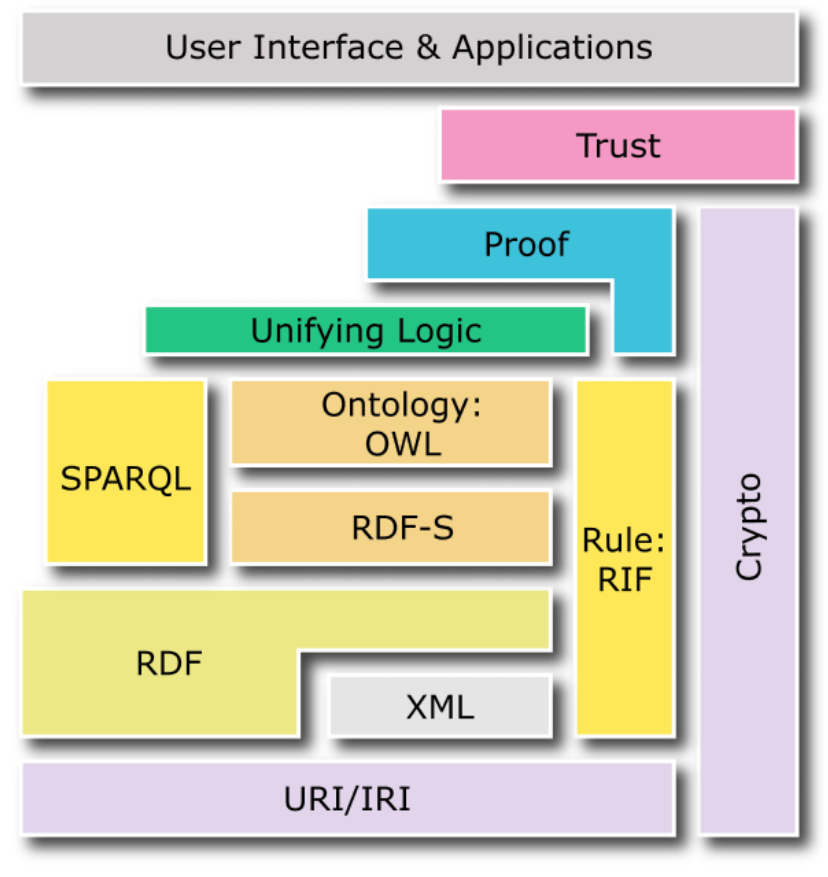

Figure 1 - The model of Semantic Web

However, finding a solution for using ontologies (as subset of classification) in HR required many years of multidisciplinary scientific research for finding answers on the questions (sorry for the mathematical jargons in advance):

- what is a correct built plane ontology?

- what is a multidimensional ontology?

- $\quad$ is correct built ontology a metric space?

- how is a dissimilarity metric defined between any two classes/concepts of ontology?

In 2016, I published an article titled "Model of computations over classifications" [6] where I provided answers to most important questions. Why is it so important? Let me explain in some simple words.

We will use a Cartesian coordinate system because it is an unified coordinate system that is the 2-dimensional variant of $n$-dimensional Euclidean space.

The Euclidian space is "very good" because it has a strong metric. We call it a distance! We use distance for any measurements and can build houses, planes, ships and a lot of other useful things. I am afraid to imagine our world without the Cartesian coordinate system - it would be going back to Stone Age. Algebra, geometry, physics, chemistry cannot exist without the Cartesian coordinate system. It is a reason why we study the Cartesian coordinate system at an early stage in school.

The same situation is with ontology/classification/taxonomy. If we can prove that a strong metrics exists as distance between two concepts/classes of ontology/classification, we can build algebra over classification.

Why we need an algebra over classification? Because knowledge of distance function between any two classes/concepts of an ontology will display what the dissimilarity distance is between two concepts. It permits us to match any two skills from skill taxonomy with some correction on dissimilarity measure. For example, let's take three skills: algebra, geometry and poetry. Clearly, skills in "algebra and geometry" are more similar than skills "algebra and poetry" or "geometry and poetry". And if we will search expert with algebra, we will rather consider a CV with geometry skill than a CV with poetry skill. A very similar situation was in Ukraine in 2012 when IT companies were searching for Scala developers. In that year a Scala developer was a very rare bird and companies interviewed Java developers because Java and Scala have the same platform and Scala permits to 
code in Java style. A correct ontology structure already defines semantic distances. Therefore, HR doesn't need to know how similar two concepts are.

Currently, there is a huge problem for using ontologies in HR - we still have not a standardized ontology of skills, competences, occupations and qualifications. However, the EC (European Commission) has started with the project ESCO - European Skills, Competences, Qualifications and Occupations [6]. I have the opportunity in taking part in pilot testing of ESCO and unfortunately, must say it needs a lot of improvement. Nevertheless, for predictive analytics in HR the following set of ontologies seems to be efficient:

a) industries;

b) structure (cross-industries, depends on industry);

c) occupations (cross-industries, depends on industry);

d) qualifications (cross-industries, depends on industry);

e) competences (soft skills)

f) hard skills - skills and knowledges (cross-industries, depends on industry);

g) locations (with levels: continent, country, region, city/village).

The indicated plain ontologies are sufficient as a base for statistical research and statistical prediction but there are some approaches of using ontology for semantic predictions. Please see examples [6]. It is very interesting for HR in behavioral predictions of a person and group of people.

I would like to say a couple words about WAND taxonomies [6]. Thanks to Ross Leher, CEO of WAND Inc., I have seen a very small fraction of taxonomies in an online demonstration but unfortunately, I was not able to examine or evaluate the correctness of WAND's taxonomies since they are intellectual properties and I do not have access to the whole structure. Wand taxonomies can be successfully used for information organization however, for using it as unified system of skills and competencies it has to be evaluated in accordance to logical division rules [6].

For example, in accordance to logical division rules the ACM classification "Computing Classification System" [6] is incorrect. It is easy to prove. The class "Network domains" is a single child of the class "Logical nodes" by path "ACM -> Networks -> Network components -> Logical nodes $->$ Network domains". In accordance to division rules any parent class has to have two or more children, otherwise single subclass has the same semantic meaning with its parent (super-class).

Recently, I had a possibility to investigate the soft-skill taxonomy of Korn \& Ferry [6] and can say that it is built with high correctness.

Clearly, the World has to have a single standardized ontology of skills, competences, occupations and qualifications. Otherwise, we have to forget about predictive analytics in HR. If you have some doubts please, take a look in the medical sphere where International Classification of Diseases already exists [6]. It means that all proprietary taxonomies will be replaced by standard taxonomies.

For example, I suggest the road map to predictive analytics in HR to be:

1. Set of standardized ontologies (industries, structures, occupations, qualifications, competencies, hard skills, locations, etc);

2. Standardized structure of vacancy profile (with hiring policy) and candidate profile;

3. Using Analytical Hierarchy Process for conversion of quality value to quantitative value;

4. Using single skill value [6] on the tuple (data structure) of "industry - location - skill proficiency level - time" in statistical methods for analysis and prediction of supply and demand particular skill on selected market.

5. Semantic prediction.

Only then, predictive analytics in HR will solve business issue that are of outmost interest to CEOs and will answer the question on: "What is the total intellectual value of a company?" This can give an answer on the question of ROI for each employee. The described approach permits to solve the problem of expert selection also.

The findings. Using ontologies is a key to solve a lot of problem on the way to the Semantic Web. It satisfies the requirements of the time and opens new opportunities, which lead to solving some well-known problem like expert selection and workforce development. 
ISSN 2411-1031. Information Technology and Security. January-June 2017. Vol. 5. Iss. 1 (8)

\section{REFERENCES}

[1] "Advanced sourcing: smart searching with more relevant keywords", Global recruiting roundtable, Aug. 2013. [Online]. Available: http://www.globalrecruitingroundtable.com/2013/ 08/31/advanced-sourcing-smart-searching-with-more-relevant-keywords-tip-4/. Accessed on: March 25, 2017.

[2] "What is semantic interoperability?", IGI Global. [Online]. Available: http://www.igiglobal.com/dictionary/semantic-interoperability/26340. Accessed on: March 25, 2017.

[3] "Compressus MEDxConnect. Top 5 Benefits of semantic interoperability", May 2015. [Online]. Available at: http://compressus.com/blog/top-5-benefits-of-semantic-interoperability. Accessed on: March 25, 2017.

[4] Tom Gruber, "Ontology", in Encyclopedia of Database Systems, Eds. New York, USA: Academic, 2009, pp. 1963-1965. doi: 10.1007/978-0-387-39940-9_1318.

[5] Reinout van Rees, "Clarity in the usage of the terms ontology, taxonomy and classification". [Online]. Available: http://reinout.vanrees.org/_downloads/2003_cib.pdf. Accessed on: March $25,2017$.

[6] "What's the difference between taxonomies and ontologies?", New Idea Engineering, Dec. 2014. [Online]. Available: http://www.ideaeng.com/taxonomies-ontologies-0602. Accessed on: March 25, 2017.

[7] "Semantic Web: Linked Data on the Web". [Online]. Available: https://www.w3.org/2007/ Talks/0130-sb-W3CTechSemWeb/\#(24). Accessed on: March 25, 2017.

[8] J. Polloc, and R. Hodgson, Adaptive Information: Improving Business Through Semantic Interoperability, Grid Computing, and Enterprise Integration, Hoboken, NJ, USA: WileyInterscience, 2004.

[9] H.A. Kravtsov, "Model of computations on classifications", Electronic Modeling, vol. 38, no. 1, pp. 73-87, 2016.

[10] "European Skills, Competences, Qualifications and Occupations", ESCO. [Online]. Available: https://ec.europa.eu/esco/portal/home. Accessed on: March 25, 2017.

[11] "Predication and ontology: the categories". [Online]. Available: https://faculty.washington.edu/ smcohen/320/cats320.htm. Accessed on: March 25, 2017.

[12] "WAND taxonomies". [Online] Available: http://www.wandinc.com/taxonomies.aspx. Accessed on: March 25, 2017.

[13] "Encyclopedia of knowledge organization. Logical division". [Online]. Available: http://www.isko.org/cyclo/logical_division. Accessed on: March 25, 2017.

[14] "The 2012 ACM Computing Classification System", Association for computing machinery. [Online]. Available: https://www.acm.org/publications/class-2012. Accessed on: March 25, 2017.

[15] "New Korn Ferry Leadership Architect Global Competency Framework", Korn Ferry. [Online]. Available: http://www.kornferry.com/products/korn-ferry-leadership-architect/kfla-overview. Accessed on: March 25, 2017.

[16] “The International Classification of Disease", World Health Organization. [Online]. Available: http://www.who.int/classifications/icd/en/. Accessed on: March 25, 2017.

[17] H. Kravtsov, "AI and predictive analytics in workforce development (WD) are trends in the future", 2017. [Online]. Available: https://www.linkedin.com/pulse/ai-predictive-analyticsworkforce-development-wd-kravtsov-ph-d. Accessed on: March 25, 2017.

The article was received 31.03.2017.

\section{СПИСОК ВИКОРИСТАНОЇ ЛІТЕРАТУРИ}

[1] "Advanced sourcing: smart searching with more relevant keywords", Global recruiting roundtable, Aug. 2013. [Online]. Available: http://www.globalrecruitingroundtable.com/2013/ 08/31/advanced-sourcing-smart-searching-with-more-relevant-keywords-tip-4/. Accessed on: March 25, 2017. 
ISSN 2411-1031. Information Technology and Security. January-June 2017. Vol. 5. Iss. 1 (8)

[2] "What is semantic interoperability?", IGI Global. [Online]. Available: http://www.igiglobal.com/dictionary/semantic-interoperability/26340. Accessed on: March 25, 2017.

[3] “Compressus MEDxConnect. Top 5 Benefits of semantic interoperability", May 2015. [Online]. Available at: http://compressus.com/blog/top-5-benefits-of-semantic-interoperability. Accessed on: March 25, 2017.

[4] Tom Gruber, "Ontology", in Encyclopedia of Database Systems, Eds. New York, USA: Academic, 2009, pp. 1963-1965.

doi: 10.1007/978-0-387-39940-9_1318.

[5] Reinout van Rees, "Clarity in the usage of the terms ontology, taxonomy and classification". [Online]. Available: http://reinout.vanrees.org/_downloads/2003_cib.pdf. Accessed on: March 25, 2017.

[6] "What's the difference between taxonomies and ontologies?", New Idea Engineering, Dec. 2014. [Online]. Available: http://www.ideaeng.com/taxonomies-ontologies-0602. Accessed on: March 25, 2017.

[7] "Semantic Web: Linked Data on the Web". [Online]. Available: https://www.w3.org/2007/ Talks/0130-sb-W3CTechSemWeb/\#(24). Accessed on: March 25, 2017.

[8] J. Polloc, and R. Hodgson, Adaptive Information: Improving Business Through Semantic Interoperability, Grid Computing, and Enterprise Integration, Hoboken, NJ, USA: WileyInterscience, 2004.

[9] H.A. Kravtsov, "Model of computations on classifications", Electronic Modeling, vol. 38, no. 1, pp. 73-87, 2016.

[10] "European Skills, Competences, Qualifications and Occupations", ESCO. [Online]. Available: https://ec.europa.eu/esco/portal/home. Accessed on: March 25, 2017.

[11] "Predication and ontology: the categories". [Online]. Available: https://faculty.washington.edu/ smcohen/320/cats320.htm. Accessed on: March 25, 2017.

[12] "WAND taxonomies". [Online] Available: http://www.wandinc.com/taxonomies.aspx. Accessed on: March 25, 2017.

[13] "Encyclopedia of knowledge organization. Logical division". [Online]. Available: http://www.isko.org/cyclo/logical_division. Accessed on: March 25, 2017.

[14] "The 2012 ACM Computing Classification System", Association for computing machinery. [Online]. Available: https://www.acm.org/publications/class-2012. Accessed on: March 25, 2017.

[15] "New Korn Ferry Leadership Architect Global Competency Framework", Korn Ferry. [Online]. Available: http://www.kornferry.com/products/korn-ferry-leadership-architect/kfla-overview. Accessed on: March 25, 2017.

[16] "The International Classification of Disease", World Health Organization. [Online]. Available: http://www.who.int/classifications/icd/en/. Accessed on: March 25, 2017.

[17] H. Kravtsov, "AI and predictive analytics in workforce development (WD) are trends in the future", 2017. [Online]. Available: https://www.linkedin.com/pulse/ai-predictive-analyticsworkforce-development-wd-kravtsov-ph-d. Accessed on: March 25, 2017.

\section{ГРИГОРІЙ КРАВЦОВ}

\section{СЕМАНТИЧНА ІНТЕРОПЕРАБЕЛЬНІСТЬ ЯК БАЗИС СЕМАНТИЧНО ЗНАЧУЩОЇ ПРЕДИКТИВНОЇ АНАЛІТИКИ}

Використання пошукових систем для знаходження експертів обмежується проблематичністю “логічного” пошуку. Зокрема, зіставлення ключових слів недостатньо для їх пошуку. Крім цього, “логічний” пошук обмежується складністю визначення пріоритетів для термів. Це означає, що вони немають ніякої функціональності для значимого аналізування. Тому головна мета статті - показати, як онтології, які є основними елементами семантичної сумісності, можуть бути використані в якості основи значущої аналітики. Це відкриває шлях вирішення багатьох проблем, серед як вибір експертів. Автор виявляє гостру проблема на межі між інформаційними технологіями та проблемами застосування логічного пошуку. У статті 
міститься реальний приклад логічного пошукового запиту щодо таких інформаційних технологій, як J2EE, JDBC, JAXB, JPA, Servlets, JAX-WS та інші. Слабкість розуміння сенсу деяких термінів призводить пошукача до неправильних результатів пошуку. Тільки онтології можуть коректно визначати синоніми та інші види відносин між двома термінами - це дуже важливо для уникнення плутанини. На жаль, існує нерозуміння сенсу наступних термінів класифікація, таксономія, онтологія. Існуючі статті не вирішують проблеми уніфікованого розуміння - це один із аспектів авторського дослідження. Автор показує, як процес аналізу ієрархії у парі з онтологіями може бути використаний для розширення можливостей існуючих підходів до вирішення проблеми відбору експертів. Всі висновки грунтуються на детальному аналізі існуючих відкритих публікацій. Вказана комбінація відкриває нові горизонти для застосування предиктивної значущої аналітики.

Ключові слова: семантична мережа, семантична інтеорперабельність, онтологія, таксономія, класифікація, інтелектуальний пошук, предиктивна аналітика, описувальна аналітика, семантично значуща аналітика.

\section{ГРИГОРИЙ КРАВЦОВ}

\section{СЕМАНТИЧЕСКАЯ ИНТЕРОППЕРАБЕЛЬНОСТЬ КАК БАЗИС СЕМАНТИЧЕСКИ ЗНАЧИМОЙ ПРЕДИКТИВНОЙ АНАЛИТИКИ}

Использование поисковых систем для нахождения экспертов ограничивается проблематичностью “логического” поиска. В частности, сопоставления ключевых слов недостаточно для поиска экспертов. Кроме того, “логический” поиск ограничивается сложностью определения приоритетов для терминов. Это означает, что они не предоставляют никакой функциональности для значимого анализа. Поэтому основная цель статьи - показать, как онтологии, являющиеся основными элементами семантической интероперабельности, могут быть использованы как основа значимой аналитики. Это открывает путь для решения множества проблем, таких как экспертный отбор. Автор обнаруживает указанную проблему на границе между информационными технологиями и проблемами использования логического поиска. В статье представлен реальный пример логического поискового запроса в отношении информационных технологий, таких как J2EE, JDBC, JAXB, JPA, Servlets, JAXWS и другие. Слабость понимания смысла некоторых терминов искателем приводит к неправильным результатам поиска. Только онтологии могут обрабатывать синонимы и другие виды отношений между двумя терминами - очень важно избегать путаницы. К сожалению, существует недопонимание смысла следующих терминов - классификация, таксономия, онтология. Существующие открытые статьи не решают проблему единого понимания - это один из аспектов исследования автора. Автор показывает, как процесс анализа иерархии в паре с онтологиями может быть использован для расширения возможностей существующих подходов к решению проблемы экспертного отбора. Все выводы основаны на детальном анализе существующих открытых публикаций. Выбранная комбинация открывает новые горизонты для прогностической значимой аналитики.

Ключевые слова: семантическая сеть, семантическая интеорперабельнисть, онтология, таксономия, классификация, интеллектуальный поиск, предиктивная аналитика, описувальна аналитика, семантически значимая аналитика.

Hryhorii Kravtsov, candidate of technical sciences, doctoral student, Pukhov Institute for modeling in energy engineering of National academy of sciences of Ukraine, Kyiv, Ukraine.

E-mail: hryhoriy.kravtsov@gmail.com.

Григорій Олексійович Кравцов, кандидат технічних наук, докторант, Інститут проблем моделювання в енергетиці ім. Г. С. Пухова Національної академії наук України, Київ, Україна.

Григорий Алексеевич Кравцов, кандидат технических наук, докторант, Институт проблем моделирования в энергетике им. Г. Е. Пухова Национальной академии наук Украины, Киев, Украина. 